\title{
Access of the patient to the cancer network under the "Sixty-Day Law": Integrative Review
}

\author{
Acesso do paciente à rede oncológica na vigência da "Lei dos Sessenta Dias": Revisão Integrativa \\ Acceso del paciente a la red oncológica en la vigencia de la "Ley de los Sesenta Días": Revisión Integrativa
}

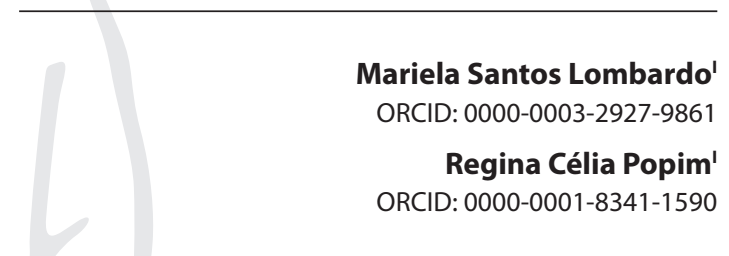

'Universidade Estadual Paulista Júlio de Mesquita Filho. Botucatu, São Paulo, Brazil.

How to cite this article:

Lombardo MS, Popim RC. Patient access to the oncology network under the "Sixty-Day Law": Integrative Review of the literature. Rev Bras Enferm. 2020;73(5):e20190406. doi: http://dx.doi.org/10.1590/0034-7167-2019-0406

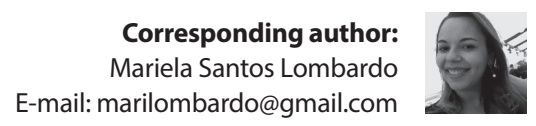

EDITOR IN CHIEF: Antonio José de Almeida Filho ASSOCIATE EDITOR: Fátima Helena Espírito Santo

Submission: 08-13-2019

Approval: 11-25-2019

\section{ABSTRACT}

Objectives: to analyze Brazilian scientific production on patient access to the oncology network under the "Sixty-Day Law". Methods: integrative review of the literature in the databases Lilacs, PubMed and Scielo. The descriptors used were: neoplasms, health services accessibility, early detection of cancer. Articles published from 2015 to March 2019 were included. Results: 17 articles were analyzed and four themes emerged: inequality in access: qualification of Primary Care professionals; time as a determinant factor; information system as limiting factor. Conclusions: the access to the oncology network is unequal and there are several barriers faced by the users. A continuing education of health professionals is necessary to implement preventive strategies. Treatment initiation is late, showing noncompliance with the law. The health care network is highly fragmented, there is lack of coordination between the services and, consequently, there is a lack of patient follow-up. Descriptors: Neoplasms; Health Services Accessibility; Early Detection of Cancer; Review; Cancer Institute.

\section{RESUMO}

Objetivos: analisar a produção científica brasileira sobre o acesso do paciente à rede oncológica na vigência da "Lei dos Sessenta Dias". Métodos: revisão integrativa realizada por meio das bases de dados: Lilacs, PubMed e Scielo. Os descritores utilizados foram: neoplasias, acesso ao serviço de saúde e diagnóstico precoce de câncer. Foram incluídos artigos publicados de 2015 a março de 2019. Resultados: foram analisados 17 artigos, dos quais emergiram quatro temas: desigualdade no acesso; a qualificação do profissional na Atenção Primária; o tempo como fator determinante; o sistema de informação como fator limitante. Conclusões: o acesso à rede oncológica é desigual, há várias barreiras enfrentadas pelos usuários. É necessária a educação permanente do profissional de saúde para lançar estratégias preventivas. $\mathrm{O}$ início do tratamento é tardio, demonstrando fragilidade na aplicação da legislação. Percebe-se que há fragmentação da rede de atenção, falta articulação entre os serviços e, consequentemente, há falta de monitoramento do paciente.

Descritores: Neoplasias; Acesso aos Serviços de Saúde; Diagnóstico Precoce de Câncer; Revisão; Instituto de Câncer.

\section{RESUMEN}

Objetivos: analizar la producción científica brasileña sobre la accesibilidad del paciente a la red oncológica, según la vigencia de la "Ley de los Sesenta Días". Métodos: se trata de una revisión integradora llevada a cabo según las bases de datos: Lilacs, PubMed y Scielo. Se utilizaron los descriptores: neoplasias, accesibilidad del servicio de salud y diagnóstico precoz del cáncer. Se incluyeron artículos publicados desde 2015 hasta marzo de 2019. Resultados: se analizaron 17 artículos, de los cuales surgieron cuatro temas: desigualdad en la accesibilidad; capacitación del profesional en la Atención Primaria; el tiempo como factor determinante; el sistema de información como factor limitador. Conclusiones: la accesibilidad de la red oncológica es desigual ya que hay muchas barreras que los usuarios deben enfrentar. La formación continua de los profesionales de la salud es imprescindible para poner en marcha estrategias preventivas. El inicio del tratamiento suele retrasarse, lo que demuestra la fragilidad en la aplicación de la legislación. Se observa la fragmentación de la red asistencial, la falta de articulación entre los servicios y como consecuencia, la falta de seguimiento de los pacientes.

Descriptores: Neoplasias; Accesibilidad de los Servicios de Salud; Diagnóstico Precoz del Cáncer; Revisión; Instituto del Cáncer. 


\section{INTRODUCTION}

Health care access is understood as the opportunity to use health services, in terms of social justice and equity. This right is established in the Brazilian legislation, which includes not only treatment, but also a broader perspective of inclusion of the individual in the health service according to their necessities and in appropriate time and places $^{(1)}$.

Primary care is the first contact between the user and the health system, and it has the role of coordinating and organizing care within the health care networks. These, in turn, are organizational arrangements with different levels of technology, aimed at providing a comprehensive care. However, Brazil's Unified Health System (SUS) is fragmented, which hinders access and does not allow a longitudinal care, compromising the comprehensiveness of the care offered ${ }^{(2)}$.

For cancer, which is considered a serious public health problem ${ }^{(3)}$, a timely access to the health care network influences the users' survival, since one of the key factors of this pathology is the time elapsed between diagnosis and initiation of treatment. For this reason, timely access is crucial ${ }^{(4)}$.

There are no global criteria on time-to-treatment. In England, for instance, patients with suspected cancer wait two weeks from the first consultation with the primary care doctor to the first specialist consultation, and after the confirmation of the diagnosis of any kind of cancer, treatment must begin in less than 31 days, with a maximum 62 days from the general practitioner referral to the start of the first treatment ${ }^{(5)}$. In Canada, the government established four different waiting times; more urgent cases have immediate treatment and aggressive cancer is treated within 14 days. The mean waiting time is 25 days, but there are records of patients who access services within an interval of 4.2 weeks ${ }^{(4,6)}$.

In Brazil, the concern towards access also includes the government institutions that implement health care laws and policies, so that diagnosis and initiation of treatment occur in a timely manner, with the objective of managing and perhaps curing the disease $\mathrm{e}^{(7)}$.

The Federal Constitution and the Organic Health Law establish that citizens have the right to healthcare, and that it is a duty of the state. However, there are many barriers to universal access to health care, which includes management and underfinancing issues. One of the important aspects is the time elapsed between diagnosis and initiation of treatment ${ }^{(8)}$. The National Congress, concerned with this issue, particularly in relation to the inclusion of this population, elaborates public policies and laws ${ }^{(7-9)}$.

In 2005, cancer begins to be regarded as a public health problem in Brazil. In the same year, the National Policy of Oncology Care is released. This policy gives priority to early diagnosis and prevention instead of treatment at advanced stages of the disease, when little can be done. The policy organizes the hierarchy of the regional care network, aiming to ensure comprehensive care. In addition, it defines the High-Complexity Cancer Units (UNACON), which have the conditions to provide assistance to the most prevalent types of cancer, including oncology surgery and clinical oncology, and the High-Complexity Cancer Centers (CACON), which have technical conditions to treat all kinds of cancers, including surgical treatment, radiotherapy and hematology, and optional pediatric services ${ }^{(10)}$.
In Brazil, Law no. 12.732 of November $22^{\text {nd }}$ came into force in 2012. It established that cancer patients have the right to initiate treatment, whether it is chemotherapy, radiotherapy or surgery, in up to sixty days from the pathological report diagnosing the disease ${ }^{(11)}$.

Considering the law that came into force in May 2013, the current scenario still does not meet current regulations. The control of the law enforcement is done through the Cancer Information System (SISCAN); however, this instrument is still not well-established, making the effective implementation of the law an important challenge ${ }^{(12)}$.

Many patients are not aware of this right, and those who are do not complain about slow services, and do not know which institutions they should seek to solve their problems. With this, early initiation of treatment, which must occur in order to increase survival rates, is not a reality for most individuals ${ }^{(13)}$.

The advances on legislation do not reflect the reality of primary care. Despite of the governmental actions, there are still gaps to be filled, as access to diagnosis remains precarious, reducing the beneficial effects of the law. About $45 \%$ of patients with cancer have their first consultation when the disease is already at an advanced stage, according to data from the Ministry of Health ${ }^{(8)}$.

The Cancer Hospital Records (CHR) of the National Cancer Institute (INCA) show that the mean waiting time for initiation of treatment is 70.3 days, according to a report of the Federal Court of Accounts(6).

In Brazil, there is no database that shows the time between diagnosis and initiation of treatment. Therefore, these values were obtained in the Apacs (Authorization for high complexity procedures), which should include data on the date of diagnosis and the beginning of high cost treatment, along with data from SIA/SUS (SUS Outpatient Information System). According to these data, the waiting time to start chemotherapy is up to 76.3 days, while for radiotherapy it is up to 113.4 days $^{(6)}$.

According to data from the TCU, the Brazilian scenario is far distant from international standards. While in Brazil about 15.9\% of patients begin chemotherapy treatment within thirty days, in Canada, $100 \%$ of patients initiate treatment in up to 30 days, and usually in the first weeks after the cancer diagnosis ${ }^{(6)}$.

In June 2018, the government approved law 13.685/18, which obliges public and private health services to notify cases of cancer in all national territory. This law came into force in December $22^{\text {th }}$, 2018. This measure aims to identify gaps in assistance, diagnosis, treatment and prevention of tumors. In addition, this law aims to obtain solid data in relation to the Sixty-Day Law, which is not observed in part of the diagnosed cases of cancer in our country.

\section{OBJECTIVES}

To analyze Brazilian scientific production on access to the oncology network under the "Sixty-Day Law".

\section{METHODS}

This is an integrative literature review, which is defined as a type of study that identifies, analyzes and synthesizes data from relevant studies in a specific topic ${ }^{(14)}$. 
Data collection occurred in April 2019 and was based on the following question: How is patient access to oncology services in Brazil after the publication of the "Sixty-Day Law"?

Based on that question, the sample was selected in the databases: Latin American and Caribbean Health Sciences Literature (LILACS), MedLine via PubMed (US National Library of Medicine PubMed Central) and Scientific Electronic Library Online (SciELo). The search strategy was composed of controlled descriptors combined with Boolean operators, arranged according to the Medical Subject Headings (MeSH): neoplasms, health services accessibility, early detection of cancer. Eligibility criteria were: full text articles, with Brazil as the study setting; studies in Portuguese, English and Spanish; articles that met the research objective: to describe the scenario of Brazil in relation to the patient diagnosed with a neoplasm and their access to health services and initiation of the treatment; studies published between 2015 and March 2019 , as the legislation came into force in 2013. Articles that did not match the objective of the study after reading the title and the abstract, articles not available in full, review articles and those that although published after 2015 had data that was collected before the "Sixty-Day Law", that is, before 2012, were excluded.

A total of 261 studies were found when crossing the descriptors, with 40 on Lilacs, 178 on PubMed and 43 on SciElo. After excluding duplicates, studies with titles/abstracts that did not correspond to eligibility criteria and studies not available in full, 37 articles were evaluated and read in full. After full reading, twenty studies were excluded, as they contained review data and data from before 2012. At the end of the selection process, the integrative review included 17 studies. The study selection flowchart for each step is shows in Figure 1, according to PRISMA (Preferred Reporting Items for Systematic Reviews and Meta-Analyses) criteria( ${ }^{(15)}$.

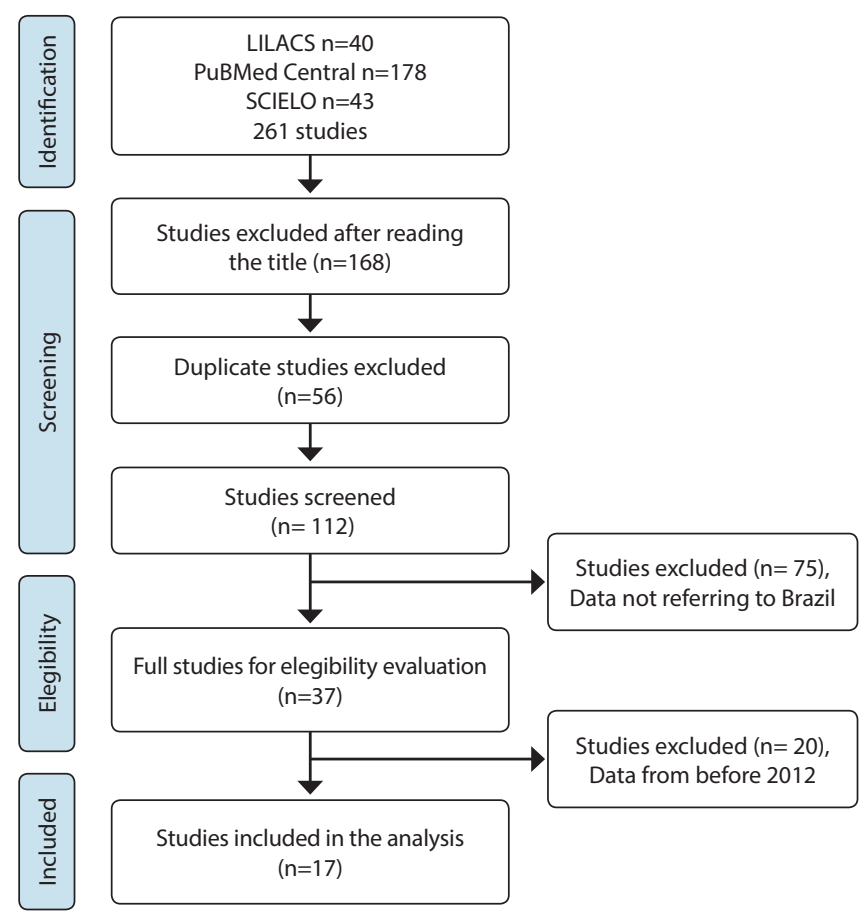

Figure 1 - Flowchart of the study selection process for the integrative review of the literature, Botucatu, São Paulo, Brazil, 2019
For data analysis, each article was read in full, in order to understand the main aspects addressed. For data interpretation, comparative reading of the articles was conducted, checking the particularities and grouping common themes into axis to be explored, using Nvivo software. The articles were inserted into the Nvivo software and after reading, excerpts were selected and formed the nodes. These were grouped by meaning and synthesized by convergence, forming the thematic categories.

The Oxford Centre for Evidence-Based Medicine categories were used to evaluate the Level of Evidence of the studies. It classified studies in six levels, being: I - Evidence resulting from meta-analysis of controlled and randomized clinical trials; II - Evidence obtained in individual studies with experimental design; III - Evidence from quasi-experimental studies; IV - Evidence from descriptive (non-experimental) or qualitative studies; $\mathrm{V}$ - Evidence from case reports or experience and VI - Evidence based on expert opinions ${ }^{(16)}$.

Four thematic categories emerged in data analysis: inequality in access; qualification of primary care professionals; time as a determining factor; the information system as a limiting factor.

The analysis and interpretation of the data were done in an organized way by means of visualization of the data in two Excel ${ }^{\circ}$ charts. The first included the following columns: authors, year of publication, level of evidence, type of study, sample and synthesis of characteristics, study setting and cancer type. Second included factors influencing access and the proposed intervention.

\section{RESULTS}

Among the 17 articles selected, most were cross-sectional studies (76.4\%), followed by qualitative studies (11,8\%). The others were quantitative, retrospective or observational (11.8\%). Regarding the level of evidence, there was a predominance of level 4. The year with most studies published was 2018 (35.4\%), followed by 2016 (29.4\%); 2017 had $17.6 \%$ of the publications, 2019 had $11.8 \%$ and 2015 had only $5.8 \%$ of the publications. Regarding the subject, $64.8 \%$ addressed breast cancer, its diagnosis and screening; $17.6 \%$ addressed cervical cancer; $5.8 \%$ were about liver cancer screening, 5.8\% about lung cancer and $5.8 \%$ did not specify the type of cancer. These data is summarized in Chart 1:

As shows in Table 1, the majority of the studies address breast cancer. Only two articles addressed the "Sixty-Day Law", highlighting the scarcity of articles analyzing its efficacy ${ }^{(23,33)}$. The importance of the time between diagnosis and treatment is recognized; however, the topics of surveillance and monitoring did not appear in the survey.

In order to highlight the thematic categories and the factors that affect access, a second table with these data was elaborated, demonstrating that there is a predominance of difficulties in access, mainly when related to socio-economic factors, and a lack of equity in access to exams and specialists consultations. Thus, the thematic categories that emerged from the study were: 1. Inequality in access; 2. Qualification of Primary Care professionals; 3. Time as a determining factor; 4. Information system as a limiting factor. 
Chart 1 - Presentation of studies included in the integrative review, according to author, year of publication, level of evidence, type of study and study data: sample, study setting and type of cancer

\begin{tabular}{|c|c|c|c|c|}
\hline $\begin{array}{l}\text { Author, year of } \\
\text { publication } \\
\text { Level of Evidence }\end{array}$ & Type of Study & $\begin{array}{l}\text { Sample and Synthesis of } \\
\text { Characteristics }\end{array}$ & Study Setting & Type of Cancer \\
\hline $\begin{array}{l}\text { Melo et al, } \\
2017^{(17)} \\
\text { LE } 4\end{array}$ & Cross-sectional Study & 113 Primary Care Nurses. & $\begin{array}{l}\text { UBS } \\
\text { City of São Paulo. Southeast } \\
\text { Region }\end{array}$ & Breast Cancer \\
\hline $\begin{array}{l}\text { Hallowell et al, } \\
2018^{(18)} \\
\text { LE } 4\end{array}$ & Cross-sectional Study & $\begin{array}{l}1251 \text { coordinators of health services, } \\
182 \text { doctors and } 347 \text { nurses. }\end{array}$ & $\begin{array}{l}\text { UBS. } \\
\text { Pelotas, Rio Grande do Sul - } \\
\text { South Region }\end{array}$ & Breast Cancer \\
\hline $\begin{array}{l}\text { Navarro et al, } \\
2015^{(19)} \\
\text { LE } 4\end{array}$ & Cross-sectional Study & $\begin{array}{l}612 \text { women between } 25 \text { and } 59 \text { years } \\
\text { old. }\end{array}$ & $\begin{array}{l}\text { Municipality of Boa Vista, } \\
\text { Roraima - North Region }\end{array}$ & Cervical Cancer \\
\hline $\begin{array}{l}\text { Silva et al, } \\
2018^{(20)} \\
\text { LE } 4\end{array}$ & Cross-sectional Study & $\begin{array}{l}\text { Distribution of mammogram } \\
\text { machines. }\end{array}$ & $\begin{array}{l}\text { State of Pernambuco, Northeast } \\
\text { Region }\end{array}$ & Breast Cancer \\
\hline $\begin{array}{l}\text { Cubero et al, } \\
2018^{(21)} \\
\text { LE } 4\end{array}$ & Cross-sectional Study & $\begin{array}{l}217 \text { cancer patients between } 20 \text { and } \\
89 \text { years old. }\end{array}$ & $\begin{array}{l}\text { UNACON São Bernardo do } \\
\text { Campo - São Paulo - Southeast } \\
\text { Region }\end{array}$ & Several types of câncer \\
\hline $\begin{array}{l}\text { Abrão et al, } \\
2017^{(22)} \\
\text { LE } 4\end{array}$ & Retrospective Study & $\begin{array}{l}509 \text { patients with malignant } \\
\text { neoplasms. }\end{array}$ & $\begin{array}{l}\text { CACON } \\
\text { São Paulo - Southeast Region }\end{array}$ & Lung Cancer \\
\hline $\begin{array}{l}\text { Barros et al, } \\
2019^{(23)} \\
\text { LE } 4\end{array}$ & Cross-sectional Study & 600 women with breast cancer. & $\begin{array}{l}\text { Public Hospitals Federal District } \\
\text { - Central-west Region. }\end{array}$ & Breast Cancer \\
\hline $\begin{array}{l}\text { Moreira et al, } \\
2018^{(24)} \\
\text { LE } 4\end{array}$ & Cross-sectional Study & $\begin{array}{l}40 \text { women between } 50 \text { and } 69 \text { years } \\
\text { old, without personal and family } \\
\text { history of cancer. }\end{array}$ & $\begin{array}{l}\text { Catholic Community. } \\
\text { Fortaleza - Ceará - Northeast } \\
\text { Region. }\end{array}$ & Breast Cancer \\
\hline $\begin{array}{l}\text { Lopes et al, } \\
2016^{(25)} \\
\text { LE } 4\end{array}$ & Cross-sectional Study & $\begin{array}{l}525 \text { women that underwent breast } \\
\text { cancer screening. }\end{array}$ & $\begin{array}{l}\text { CACON } \\
\text { South Region. }\end{array}$ & Breast Cancer \\
\hline $\begin{array}{l}\text { Bezerra et al, } \\
2018^{(26)} \\
\text { LE } 4\end{array}$ & Qualitative Study & $\begin{array}{l}26 \text { women between } 47 \text { and } 56 \text { years } \\
\text { old with breast cancer. }\end{array}$ & $\begin{array}{l}\text { Outpatient Cancer Center } \\
\text { Fortaleza - Ceará - Northeast } \\
\text { Region. }\end{array}$ & Breast Cancer \\
\hline $\begin{array}{l}\text { Souza et al, } \\
2017^{(27)} \\
\text { LE } 4\end{array}$ & Cross-sectional Study & $\begin{array}{l}241 \text { women between } 40 \text { and } 69 \text { years } \\
\text { old. }\end{array}$ & $\begin{array}{l}\text { Households. } \\
\text { Boa Vista - Roraima - North } \\
\text { Region. }\end{array}$ & Breast Cancer \\
\hline $\begin{array}{l}\text { Barcelos et al, } \\
2017^{(28)} \\
\text { LE } 4\end{array}$ & $\begin{array}{l}\text { Quantitative } \\
\text { Observational Study }\end{array}$ & $\begin{array}{l}35.844 \text { women between } 25 \text { and } 64 \\
\text { years old. }\end{array}$ & $\begin{array}{l}\text { UBS. North, Northeast, } \\
\text { Midwest, Southeast and South } \\
\text { Regions. }\end{array}$ & Cervical Cancer \\
\hline $\begin{array}{l}\text { Moraes et al, } \\
2016^{(29)} \\
\text { LE } 4\end{array}$ & Cross-sectional Study & 60 primary care nurses. & $\begin{array}{l}\text { UBS. Ribeirão Preto - São Paulo } \\
\text { - Southeast Region }\end{array}$ & Breast Cancer \\
\hline $\begin{array}{l}\text { Silva et al, } \\
2019^{(30)} \\
\text { LE } 4\end{array}$ & Cross-sectional Study & $\begin{array}{l}400 \text { women between } 40 \text { and } 59 \text { years } \\
\text { old in health units. }\end{array}$ & $\begin{array}{l}\text { ESF. } \\
\text { Vitória - Espírito Santo - } \\
\text { Southeast Region. }\end{array}$ & Breast Cancer \\
\hline $\begin{array}{l}\text { Signorelli et al, } \\
2016^{(31)} \\
\text { LE } 4\end{array}$ & Cross-sectional Study & $\begin{array}{l}253 \text { cirrhotic patients, } 177 \text { from public } \\
\text { hospitals and } 76 \text { from the private } \\
\text { sector. }\end{array}$ & $\begin{array}{l}\text { Private Hospital and University } \\
\text { Hospital. } \\
\text { Vitória - Espírito Santo - } \\
\text { Southeast Region. }\end{array}$ & $\begin{array}{l}\text { Hepatocellular } \\
\text { Carcinoma }\end{array}$ \\
\hline $\begin{array}{l}\text { Rocha-Brishillari et } \\
\text { al 2018 } \\
\text { LE 2C }\end{array}$ & $\begin{array}{l}\text { Ecological, Descriptive } \\
\text { and Analytical Study }\end{array}$ & $\begin{array}{l}\text { To analyze socio-economic and access } \\
\text { disparities related to breast cancer } \\
\text { mortality in } 399 \text { cities in the state of } \\
\text { Paraná, Brazil. }\end{array}$ & Paraná - South Region. & Breast Cancer \\
\hline $\begin{array}{l}\text { Carvalho et al, } \\
2018^{(33)} \\
\text { LE } 4\end{array}$ & $\begin{array}{l}\text { Cross-sectional and } \\
\text { Qualitative Study }\end{array}$ & $\begin{array}{l}174 \text { medical records of women with } \\
\text { malignant breast cancer, with } 05 \text { of } \\
\text { these in the qualitative stage, between } \\
31 \text { and } 60 \text { years old. }\end{array}$ & $\begin{array}{l}\text { CACON Rio de Janeiro - } \\
\text { Southeast Region. }\end{array}$ & Cervical Cancer \\
\hline
\end{tabular}

Note: UBS - Primary Care Unit; ESF - Family Health Strategy; CACON - High-Complexity Cancer Center; UNACON - High-Complexity Cancer Unit. 
Chart 2 - Presentation of thematic categories of patient access to the oncology network under the "Sixty-Day Law", according to evidence and articles analyzed, 2019

\begin{tabular}{|c|c|c|}
\hline Category & Evidence & Articles \\
\hline \multirow[t]{4}{*}{ Inequality in access } & $\begin{array}{l}\text { Preventive examination conducted on opportunity, not favoring prevention } \\
\text { Difficulty to make appointments and schedule exams, and lack of professionals }\end{array}$ & $\begin{array}{l}18,19,20,26 \\
\quad 27,31\end{array}$ \\
\hline & $\begin{array}{l}\text { Equipment poorly distributed, allocated in large centers to the detriment of places with higher incidence } \\
\text { of the disease; lack of a coordinated care network }\end{array}$ & $20,21,25,32,33$ \\
\hline & $\begin{array}{l}\text { Primary care does not meet the demand. It also takes time to perform the exams. Private examinations } \\
\text { are performed for faster diagnosis. }\end{array}$ & $22,23,29$ \\
\hline & $\begin{array}{l}\text { Socio-economic factors show that access is favorable for users with more years of education and higher } \\
\text { purchasing power }\end{array}$ & $24,27,28,30$ \\
\hline \multirow{3}{*}{$\begin{array}{l}\text { Qualification } \\
\text { of Primary Care } \\
\text { professionals }\end{array}$} & $\begin{array}{l}\text { Primary Care health professionals do not have enough knowledge on INCA guidelines to conduct } \\
\text { effective screening }\end{array}$ & $\begin{array}{l}17,18,22,25,26 \\
27,29\end{array}$ \\
\hline & Work overload leads to superficial care and no active search for altered exams nor preventive activities & $19,28,31,32$ \\
\hline & Primary care professionals do not organize and coordinate care & $23,29,30,32,33$ \\
\hline \multirow{3}{*}{$\begin{array}{l}\text { Time as } \\
\text { determining fator }\end{array}$} & Lack of equity in access means more time for doing exams. & 17,30 \\
\hline & It takes time to get consultations and examinations by the SUS, which is not in the line with guidelines & $18,26,33$ \\
\hline & Reduced diagnostic time is achieved by private-sector examinations & $22,23,31$ \\
\hline \multirow[t]{2}{*}{$\begin{array}{l}\text { Information system } \\
\text { as limiting factor }\end{array}$} & $\begin{array}{l}\text { Monitoring system implemented by the Ministry of Health is not properly filled. Professionals do not } \\
\text { know how to use the platforms }\end{array}$ & $17,20,29$ \\
\hline & $\begin{array}{l}\text { Lack of a system to monitor individuals who are examined, leading to over-examination of some and } \\
\text { lack of examination of others }\end{array}$ & $18,21,26,29$ \\
\hline
\end{tabular}

Note: INCA - National Cancer Institute; SUS - Brazil's Unified Health System.

\section{DISCUSSION}

Difficulty in access to health services such as consultations and examinations is related to geographic, socio-economic and cultural factors. It is also associated with the qualification of professionals, who require continuing education focused on risk factors and prevention of various types of cancer. When there is no equal access and services are unavailable, there is a delay in diagnosis. Patients are not monitored as soon as symptoms begin or diagnosis is made, demonstrating the need for an effective information system.

\section{Inequality in access}

The most prevalent theme was unequal access to services. In this context, low socio-economic level and low level of education are highlighted as factors that hinder access. The World Health Organization (WHO) mentions that the current inequality in several countries is a limiting factor for access to care $^{(34)}$.

In addition to inequality, there are also factors related to intersectoral actions and social and economic policies that can mitigate differences in income and education ${ }^{(3)}$. Level of education is one of the aspects that hinder access to breast cancer screening: more years of education are associated with a greater chance of adherence to examinations ${ }^{(24-27)}$. Individuals with a low level of education do not recognize the importance of the examination, and end up not performing it ${ }^{(18-20,30,32)}$. According to WHO studies, cancer has greater impact in low-income countries, where education is precarious, which is associated with low self-care, corroborating the collected data ${ }^{(2,34)}$.

Knowledge on breast and cervical cancer is a little more disseminated to the population, and there are government programs that encourage screening. However, for some types of cancer such as lung and liver cancer, early detection programs are still scarce ${ }^{(22,28)}$. Financial, cultural, social and geographic barriers impede timely access to adequate resources. Lack of investment in prevention programs, especially in primary care, is also a limiting factor ${ }^{(35-36)}$.

According to some studies, the SUS is seen by the population as a system with a time-consuming service, mainly when it comes to specialist consultations and diagnostic examinations. For this reason, some users choose the private system to perform preventive examinations ${ }^{(23,26)}$. Access to private service corroborates the relationship between socio-economic factors and access to health care services, as people with low income cannot access these services. This demonstrates that it is necessary to overcome important barriers to start treatment in the SUS ${ }^{(23,25)}$. The use of private services is common in low and middle income countries, because besides the low supply, the population does not trust the quality of the public service offered ${ }^{(35)}$.

Difficulties to access examinations in the care network are an important factor for the delay in treatment initiation, leading to non-compliance with the "Sixty-Day Law". Prevention still is the best way to cure the disease. Therefore, it is necessary to invest in Primary care in order to increase survival rates ${ }^{(36)}$.

Another problem is lack of equipment such as mammogram machines ${ }^{(20)}$. There is a discrepancy in distribution of technology for early diagnosis, and most of the time these tools are concentrated in certain regions of the country or of each state, mainly in more developed regions, which do not always have the highest prevalence of the disease ${ }^{(25-26)}$. This misallocation leads to inequality, as some women perform the examination more times that needed, while some have never performed them ${ }^{(33)}$.

There is a huge global inequality in access to cancer care and a disparity in initiation of treatment, dividing cancer care 
between rich and poor countries and highlighting that access to diagnosis is limited in low-income countries ${ }^{(4,17,37)}$. There is a law for early treatment, however, it does not provide materials and supplies to guarantee it.

Regarding this inequality in access to both diagnosis and treatment, one study stressed that patients have to move to different cities to get consultations and have their needs met. Patient migrate between cities and even between states, further demonstrating inequality of access ${ }^{(21,26)}$. Waiting lines delay diagnosis and treatment, and studies show that in addition to migration, networks of friends are used to gain access to treatment, not obeying the flow established in the territory ${ }^{(28,32)}$. Regarding cervical cancer, studies show that the South and Southeast regions of Brazil have the best indicators regarding the screening of this disease ${ }^{(28,33)}$. Advances in treatment in certain regions and countries demonstrates unequal access, as rich countries have earlier detection of the disease and deliver better results to the users ${ }^{(34)}$.

The reality of patients, associated with lack of knowledge, make them dependent on health professionals, as they are unaware of the need for self-care ${ }^{(28,33)}$. In addition to the unawareness of patients, there are also scarcities in the system and lack of periodic medical appointments ${ }^{(27,30-31)}$. For some users, examination such as mammography, ultrasound and pap smear are associated with preventive practices ${ }^{(19,30)}$.

Users are used to the process of complaint-conduct, not to the reality of prevention. Therefore, they seek health services only when they have a complaint, and then care is based on the disease $\mathrm{e}^{(19,33)}$.

Socioeconomically disadvantaged groups are more vulnerable because they are unfairly exposed to risk factors and have limited access to diagnostic and care services ${ }^{(34)}$. According to the $\mathrm{WHO}$, about $1 / 3$ of cancer cases are preventable. However, this requires focus on prevention, reduction of risk factors and early identification of cancer. These factors can reduce costs and increase the likelihood of cure ${ }^{(34)}$.

Thus, compliance with the law is impaired by several factors that delay diagnosis, demonstrating that there is a problem in the basis of the system, associated with poor distribution of equipment and of services that allow early diagnosis.

\section{Qualification of primary care professionals}

Another aspect that was highlighted was the qualification of the professionals and how it can help or delay cancer screening. Studies with nurses shows that they do not receive any training for cancer screening, which sometimes leads to false screening ${ }^{(17,29-30,32,35)}$.

Professional continuing education is a necessity, as shown by several studies, specially regarding the protocols used in primary care and the INCA recommendations, which are aimed at reducing misconducts ${ }^{(17-18)}$. Lack of qualification makes professionals insecure to perform certain actions and rely on the prevailing model of complaint-conduct ${ }^{(29-30)}$. Optimizing the use of human resources and their skills and abilities favors cancer prevention and control ${ }^{(19)}$. This can increase compliance with the legislation of the oncology care network.

In addition, a study noted that the best way to improve women's adherence to screening examination is through effective communication between health professionals and patients ${ }^{(26)}$. Quality care favors customer service. Therefore, the professionals must be trained according to the reality of the patients ${ }^{(33)}$. In addition, professionals must be aware of the importance of early cancer detection, not only through their education, but through training within their work processes, encouraging the continuing education of new professionals (27-28,30). $^{\text {. }}$

Investments in nurses and in other health professionals can have a positive influence on the outcomes regarding cervical and breast cancer. This is specially important in Primary Care, where professionals are inserted in the community and are considered a bridge for specialists and advanced treatment centers ${ }^{(35)}$.

The difficulties present in the health system are mostly related to the structure of care networks, as there is evidence of demands higher than what the system can provide, delays in consultations and examinations, and limited time to provide quality patient care $^{(23,31-33)}$. The lack of standard protocols adds to this difficulty. For example, lack of knowledge of the recommended age for breast cancer screening leads to excessive examination requests and no follow-up of abnormal tests ${ }^{(18,27)}$.

The role of Primary Health Care (PHC) is essential for proper screening, as it is considered the gateway to other services. However, studies show a need for improvement in staffing, and demonstrate that $\mathrm{PHC}$ should play its fundamental role, organizing access by giving priority to cases according to the risk classification established ${ }^{(23,28,32)}$. The way the service is offered in PHC may sometimes hinder the screening process. It is necessary to adapt the structure and the work process ${ }^{(19,29)}$. In PHC, the work must be based on prevention, and this, in turn, is related to the time available to assist the user and the involvement of the professionals in educational actions that can enhance screening. The importance of the nurse as a care provider is also highlighted and is often limited, as some competences are restricted to doctors ${ }^{(26,29,35)}$.

Studies also show failure to perform active search, focused on preventive actions rather than on signs and symptoms ${ }^{(25,28)}$. Prevention is not done periodically, but on opportunities, when users arrive in the health unit for other reasons and end up being screened ${ }^{(19,27)}$. However, this implies favoring those who seek the unit over others who do not go to the PHC, demonstrating that there is a need to implement active search and awareness practices in user care ${ }^{(19,26,29)}$.

Screening and active search are performed only when there are altered examinations, but not for missing individuals; thus, it is necessary to seek those who do not go to the primary care unit ${ }^{(17,30)}$. According to some studies, this may be associated with service overload ${ }^{(33)}$.

Effective cancer control requires a universal health care system based on Primary Care and strengthening of the national health care system ${ }^{(4)}$. Health care should not only focus in prevention, but also in timely access to treatment and care ${ }^{(34)}$.

Inadequate professional qualification and difficulty of access lead to ineffective screening, as there is no examination available for the population. High demand when there is no eligibility criteria reflects the inability of the health system to meet the demands of all patients ${ }^{(18,22)}$.

In addition to the difficulty to perform screening tests, there is also a shortage of complex examinations, such as biopsy. Also, 
the user needs to travel between different services in order to have their needs met $^{(23,33)}$. Lack of interest to provide adequate treatment to the patient and inequality between the regions of the country were also related to failure in effective screening ${ }^{(26,28,30)}$.

Regarding liver cancer, it is necessary to perform periodic examinations on patients who already have cirrhosis. However, lack of opportunity and of professional knowledge leads to ineffectiveness in disease screening and control ${ }^{(31)}$. Time issues, mainly among professionals, were also associated with ineffective screening. Health services should provide the user with the opportunity to perform the tests, focusing on the equity of access ${ }^{(29,32-33)}$.

Therefore, lack of professional training, associated with overload in the services, leads to precarious care and reduces compliance with the "Sixty-Day Law", as professionals are unaware of the importance of screening and active search.

\section{Time as a determining factor}

Among all the difficulties exposed, a very common topic in the articles concerns time, mainly regarding delay in examinations and return to consultations. These periods are over 90 days in most studies, reaching 211.8 days. This means that treatment is initiated when the disease is already in an advanced state $\mathrm{s}^{(17,22-23)}$. Time is directly associated with access to specialist consultations. According to the articles, when there is consultation with specialist there is a reduction in time-to-treatment ${ }^{(18,30)}$. The time interval is extended when the patient is totally dependent on the SUS ${ }^{(33)}$. Thus, there is no compliance with the "Sixty-Day Law" and time-to-treatment may exceed the recommended period up to three-fold.

When related to the socio-economic factor, time is reduced when the patient uses a mixed system. This is also perceived when the service cannot provide a schedule and available professionals ${ }^{(26,33)}$. Overdemand in the entire healthcare system is directly associated with delayed diagnosis. The studies demonstrate the inefficiency of the system and the lack of guarantee of continuity of care $\mathrm{e}^{(26,33)}$.

A study in Malaysia found that in low-income countries with major social inequalities about 50 to $88 \%$ of deaths would be preventable if cancer diagnosis was early and individuals had optimal access to the service. Patients diagnosed with cancer should have immediate access to optimal treatment to increase their survival chances ${ }^{(36-37)}$.

Regarding the topic of time and the need to reduce it, identified in several studies, the current legislation on timely care is not adequately addressed in the articles, as only two stressed the importance of the law and showed that the services do not comply with the maximum time described in the legislation. Only a small portion of the users can access care in the time established ${ }^{(23,33)}$. Economic and fiscal policies are powerful tools to improve health equity, promote better cancer outcomes and increase compliance with legislation ${ }^{(35)}$.

\section{Information system as limiting factor}

Despite of the law, there is no instrument for law enforcement, and six studies highlight the importance of an effective information system, as the existing platform is not used by health units, which leads to unplanned care and lack of monitoring of actions taken ${ }^{(17-18,20-21,26,29)}$. The lack of computerized monitoring also leads to lack of follow-up regarding time, and some individuals end up doing too many examinations ${ }^{(18,20,26)}$. Effective surveillance favors cost-effective health care ${ }^{(17,21)}$.

Effective cancer control requires adequate resources to understand the local reality and act according to its needs, allowing a follow-up of the user in the system ${ }^{(34)}$.

An effective system allows monitoring the users' path in the care network. This would avoid excessive costs, empower professionals with the knowledge of their reality and favor law enforcement. An efficient information system was considered a key tool for the coordination of services ${ }^{(21,26,29)}$. One of the possibilities to improve the information system is the e-SUS tool proposed by the Ministry of Health as a strategy for developing, restructuring and ensuring integration between systems and providing a single record of the users' health status across the national health system. The purpose of the platform is to organize the work of professionals, aiming at providing a quality health service to the population ${ }^{(12)}$.

Reports and robust monitoring and evaluation systems are effective strategies to improve action planning and ensure quality and implementation when it comes to cancer control ${ }^{(2,34)}$.

\section{Study limitations}

The limitation of the study was the lack of articles with high scientific evidence, as shown in Table 1. Most studies provided cross-sectional data based on a single type of cancer and did not have data on the actual access time during the individual's trajectory in the system.

\section{Contributions to Nursing and Public Health}

The study demonstrated the reality of access to the oncology network in different regions of Brazil, showing how this access occurs and highlighting its advantages and difficulties. It also showed that nursing professionals are essential for preventive cancer care, especially regarding breast and cervical cancer, emphasizing the need to reaffirm the autonomy of nursing professionals in the evaluation, examination requests and referrals in these cases.

\section{CONCLUSIONS}

There are inequalities in access to the oncology network, marked by financial, cultural, social and geographic barriers that hinder access to the health system and consequently lead to late diagnosis and initiation of treatment. As Brazil is a country of continental dimensions, there is unequal supply of health services, compelling the user to move to more equipped and developed cities in search of care. In addition, Primary Care is not effective in its role of providing preventive actions, due to the high demand of users who focus on symptoms, the scarcity of resources and the precarious continuing education of Primary Care professionals that provide care to this user.

Despite of the legislation on timely access, Primary Care and Specialized Care have difficulties providing exams and appointments. In addition, the care network is highly fragmented, which 
is demonstrated by the lack of coordination between services and referral and counter-referrals in different levels of attention. An effective monitoring of this user is required and should occur through a connected information logging system, which can favor early diagnosis and timely treatment.

Finally, this study may contribute to the implementation of protocols in Primary Care, in order to ensure better access to the cancer patient. Further research on the "Sixty-Day Law" is necessary to clarify its shortcomings and its effectiveness.

\section{FUNDING}

This article is part of an Approved and Financed Project by grant: 2016/09780-7, São Paulo Reseach Foundation (FAPESP).

\section{REFERENCES}

1. Sanchez RM, Cicconelli RM. Conceitos de acesso à saúde. Rev Panam Salud Publica [Internet]. 2012 [cited 2019 Jan 29];31(3):260-8. Available from: https://www.scielosp.org/pdf/rpsp/2012.v31n3/260-268/pt

2. Lavras, C. Atenção primária à saúde e a organização de redes regionais de atenção à saúde no Brasil. Saude Soc. 2011;20(4):867-74. doi: 10.1590/S0104-12902011000400005

3. Bray F, Ferlay J, Soerjomataram I, Siegel RL, Torre LA, Jemal A. Global cancer statistics 2018: GLOBOCAN estimates of incidence and mortality worldwide for 36 cancers in 185 countries. Ca Cancer J Clin [Internet]. 2018 [cited 2019 Apr 20];68:394-424. doi: 10.3322/caac.21492

4. World Health Organization. Fifty-eight World Health Assembly: cancer prevention and control [Internet]. WHO, Geneva; 2017[cited 2019 Jan 29]. Available from: https://www.who.int/cancer/media/news/WHA58\%2022-en.pdf?ua=1

5. Di Girolamo C, Walters S, Gildea C, Benitez Majano S, Rachet B, Morris M. Can we assess Cancer Waiting Time targets with câncer survival? a population-based study of individually linked data from the National Cancer Waiting Times monitoring dataset in England, 2009-2013. PLoS ONE. 2018;13(8):e0201288. doi: 10.1371/journal.pone.0201288

6. Tribunal de Contas da União (BR). Política Nacional de Atenção Oncológica [Internet]. Relator Ministro José Jorge. Brasília. TCU, Secretaria de Fiscalização e Avaliação de Programas do Governo, 2011 [cited 2019 Mar 11]. Available from: https://portal.tcu.gov.br/lumis/portal/file/ fileDownload .jsp?inline=1\&fileld=8A8182A14D6E85DD014D7327C1CB5497

7. Iturri JA. Acesso e Integralidade da atenção. Rev Tempus Actas Saúde Colet [Internet]. 2014 [cited 2019 Mar 10];8(1):85-90. Available from: http://www.tempusactas.unb.br/index.php/tempus/article/view/1457/1301

8. Gomes FBC. Lei sobre tratamento de câncer no SUS: análise dos dispositivos e perspectivas. Cad Ibero-amer Dir Sanit [Internet]. 2013 [cited 2019 Feb 01];2(1):81-87. Available from: https://www.cadernos.prodisa.fiocruz.br/index.php/cadernos/article/view/31/69

9. Zillmer JGV, Lima LM, Feijó AM, Schwartz E, Hisse CN, Viegas AC, et al. Caracterização dos Clientes em tratamento radioterápico em um serviço no sul do Brasil. Rev Enferm UFSM. 2013;3(2)315-25. doi: 10.5902/217976928595

10. Correa MCMMA, Naffah FM, Cecilio MAM, Tamelini RM. Diretrizes para atenção oncológica no estado de São Paulo: contribuições para o debate. BEPA Bol Epidemiol Paulista [Internet]. 2011 [cited 2019 Jan 29];92(8):24-43. Available from: http://periodicos.ses.sp.bvs.br/pdf/bepa/v8n92/v8n92a03.pdf

11. Casa Civil da Presidência da República (BR). Lei no 12.732 de 22 de novembro de 2012. Dispõe sobre o primeiro tratamento de paciente com neoplasia maligna comprovada e estabelece prazo para seu início [Internet]. Brasília; 2012 [cited 2019 Mar 11]. Available from: http://www. planalto.gov.br/ccivil_03/_ato2011_2014/2012/lei/l12732.htm

12. Panitz LM. Registro eletrônico de saúde e produção de informações da atenção à saúde no SUS. [Dissertação] [Internet]. Escola Nacional de Saúde Pública Sérgio Arouca; 2014. Available from: https://www.arca.fiocruz.br/bitstream/icict/23778/1/ve_Leandro_Manassi_ENSP_2014

13. Sonobe HM, Buetto LS, Zago MMF. Cancer patients' knowledge about their legal rights. Rev Esc Enferm USP [Internet]. 2011 [cited 2019 Feb 01];46(2):339-45. Available from: http://www.scielo.br/pdf/reeusp/v45n2/en_v45n2a05.pdf

14. Ganong LH. Integrative Reviews of Nursing Research. Res Nurs Health. 1987;10(1):1-11

15. Stewart LA, Clarke M, Rovers M, Riley RD, Simmonds M, Stewart G, Tierney JF. PRISMA-IPD Development Group. Preferred Reporting Items for Systematic Review and Meta-Analyses of individual participant data: the PRISMA-IPD Statement. JAMA [Internet]. 2015 [cited 2019 Feb 02];313(16):1657-65. Available from: https://jamanetwork.com/journals/jama/fullarticle/2279718

16. Oxford Centre for Evidence-based Medicine: levels of evidence [Internet]. 2009 [cited 2019 Oct 10]. Available from: http://www.cebm.net/ oxford-centre-evidence-based-medicine-levels-evidencemarch-2009

17. Melo FBB, Marques CAV, Rosa AS, Figueiredo EN, Gutiérrez MGR. Actions of nurses in early detection of breast cancer. Rev Bras Enferm. 2017;70(6):1119-28. doi: 10.1590/0034-7167-2016-0155

18. Hallowell BD, Perin DMP, Simoes EJ, Paez DC, Parra DC, Brownson RC, Saraiya M. Breast cancer related perceptions and practices of health professionals working in Brazil's network of primary care units. Prev Med. 2018;106(1):216-23. doi: 10.1016/j.ypmed.2017.11.002

19. Navarro C, Fonseca AJ, Sibajev A, Souza CIA, Araújo DS, Teles DAF, et al. Cervical cancer screening coverage in a high-incidence region. Rev Saúde Pública. 2015;49:17. doi: 10.1590/S0034-8910.2015049005554

20. Silva MTA, Silva Jr VB, Mangueira JO, Gurgel Jr GD, Leal EMM. Distribution of mammograms and mammography offering in relation to the parametric care of the Public Health Care System in Pernambuco. Rev Bras Saúde Mater Infant. 2018;18(3):609-18. doi: 10.1590/1806-93042018000300009 
21. Cubero DIG, Steete CVM, Piscopo BCP, Monteiro CRA, Schouer JHM, Tavares HDA, et al. Epidemiological profile of Brazilian oncological patients seen by a reference oncology center of the public health system and who migrate in search of adequate health care. Rev Assoc Med Bras. 2018;64(9):814:8. doi: 10.1590/1806-9282.64.09.814

22. Abrão FC, Abreu IRLB, Rocha RO, Munhoz FD, Rodrigues JHG, Younes RN. Impact of the delay to start treatment in patients with lung cancer treated in a densely populated area of Brazil. Clinics. 2017;72(11):675-80. 10.11606/s1518-8787.2019053000406

23. Barros AF, Araújo JM, Murta-Nascimento C, Dias A. Clinical pathways of breast câncer patients treated in the Federal District, Brazil. Rev Saude Publica. 2019;53:14. doi: 10.11606/s1518-8787.2019053000406

24. Moreira CB, Fernandes AFC, Castro RCMB, Oliveira RDP, Pinheiro AKB. Social determinants of health related to adhesion to mammography screening. Rev Bras Enferm. 2018;71(1):97-103. doi: 10.1590/0034-7167-2016-0623

25. Lopes TCR, Gravena AAF, Demitto MO, Brischiliari SCR, Borghesan DHP, Agnolo CM, et al. Mammographic screening of women attending a reference service center in Southern Brazil. Asian Pac J Cancer Prev. 2016;17(3):1385-91. doi: 10.7314/APJCP.2016.17.3.1385

26. Bezerra IC, Silva RM, Oliveira CP, Brasil CCP, Vasconcelos MGF, Mamede MV, Oliveira MTP. Mastectomized women's perception of breast cancer early detection. PLoS One. 2018;13(11):e0206405. doi: 10.1371/journal.pone.0206405

27. Souza CIA, Araújo DS, Teles DAF, Carvalho SGL, Cavalcante KWM, Rabelo WL, et al. Factors related to non-adherence to mammography in a city of the Brazilian Amazonian area: a population-based study. Rev Assoc Med Bras. 2017;63(1):35-42. doi: 10.1590/1806-9282.63.01.35

28. Barcelos MRB, Lima RCD, Tomasi E, Nunes BP, Duro SMS, Facchini LA. Quality of cervical cancer screening in Brazil: external assessment of the PMAQ. Rev Saude Publica. 2017;51:67. doi: 10.1590/s1518-8787.2017051006802

29. Moraes DC, Almeida AM, Figueiredo EM, Loyola EAC, Panobianco MS. Opportunistic screening actions for breast cancer performed by nurses working in primary health care. Rev Esc Enferm USP. 2016;50(1):14-21. doi: 10.1590/S0080-623420160000100002

30. Silva RP, Gigante DP, Amorim MHC, Leite FMC. Factors associated with having mammography examinations in primary health care users in Vitória, Espírito Santo, Brazil. Epidemiol Serv Saúde [Internet]. 2019 [cited 2019 Apr 12];28(1):e2018048. Available from: http://www.scielo. br/pdf/ress/v28n1/en_2237-9622-ress-28-01-e2018048.pdf

31. Signorelli IV, Gonçalves PL, Gonçalves LL, Ferreira LSE, Mendonça ATP, Franklin GL, et al. Socioeconomic disparities in access to a hepatocellular carcinoma screening program in Brazil. Clinics [Internet]. 2016 [cited 2019 Apr 14];71(7):361-364. doi: 10.6061/ clinics/2016(07)01

32. Rocha-Brischillari SC, Andrade L, Nihel OK, Brischillari A, Hortelan MS, Carvalho MDB, et al. Spatial distribution of breast cancer mortality: Socioeconomic disparities and access to treatment in the state of Parana, Brazil. PLoS One. 2018;13(10):e0205253. doi: 10.1371/journal. pone.0205253

33. Carvalho PGC, O'D wer G, Rodrigues NCP. Health assistance path of women between diagnosis and treatment initiation for cervix câncer. Saúde Debate [Internet]. 2018 [cited 2019 Apr 14];42(118):687-701. Available from: http://www.scielo.br/pdf/sdeb/v42n118/en_0103-1104sdeb-42-118-0687.pdf

34. World Health Organization-WHO. Cancer prevention and control in the context of an integrated approach: report by the Secretariat [Internet].WHO, Geneva; 2016 [cited 2019 Apr 29]. Available from: https://apps.who.int/gb/ebwha/pdf_files/EB140/B140_31-en.pdf

35. Ginsburg O, Badwe R, Boyle P, Derricks G, Dare A, Evans T, et al. Changing global policy to deliver safe, equitable and affordable care for women's cancers. Lancet [Internet]. 2017 [cited 2019 Apr 25];389:871-80. Available from: https://www.ncbi.nlm.nih.gov/pubmed/27814964

36. Coleman MP. The concord programme: Why we need global surveillance of cancer survival. Cancer Control [Internet]. 2013[cited 2019 Apr 20]:60-65. Available from: http://cancercontrol.info/wp-content/uploads/2014/08/cc2013_60-65-Michel-P-Coleman_2013.pdf

37. Ho GF, Taib NA, Pritam Singh RK, Yip CH, Abdullah MM, Lim TO. What if all patients with breast cancer in Malaysia have access to the best available care: how many deaths are avoidable?. Glob J Health Sci. 2017;9:32-9. doi: 10.5539/gjhs.v9n8p32 